\title{
KONTRIBUSI PEMIKIRAN \\ EGBERT SCHUURMAN \\ MENGENAI PERMASALAHAN DAN SOLUSI TEKNOLOGI MODERN
}

\author{
Adrian Jonatan \\ Gereja Reformed Injili Indonesia
}

\begin{abstract}
In the modern technological world, human is constantly relating with technology, be it as a user or as a part of technological production mechanism. But what is technology, what kind of value that technology brings, and how should one response to technology? Does technology brings good, bad or neutral? These are the questions that we need to answer as we live in a technological world. In the philosophy of technology, there is one thinker, who represents the school of Reformational Philosophy, named Egbert Schuurman. In the midst of two kinds of reaction towards technology (optimistic and pessimistic) Schuurman proposes a Liberating Perspective as the third option. This perspective is aware of the deep influence of human sinfulness in technological development. However, it also considers the beauty of creational design and Christ's redeeming power for technological development. In this article, the writer would like to observe Schuurman's thoughts regarding this Liberating Perspective as a considerable solution to the problems of modern technological life.
\end{abstract}


KEYWORDS: technology, modern, society, reformational philosophy, liberating perspectives, responsible ethics.

ABSTRAK: Manusia senantiasa berhubungan dengan teknologi, baik sebagai pengguna, maupun sebagai bagian dari pembuat produk teknologi. Apakah teknologi itu, dan apakah nilai yang terdapat di dalamnya, serta bagaimanakah manusia seharusnya bersikap terhadap teknologi? Dalam filsafat teknologi ada seorang pemikir yang mewakili pemikiran filsafat reformasional terhadap teknologi, yakni Egbert Schuurman. Di tengah dua arus pandangan, baik optimis maupun persimis, terhadap teknologi, Schuurman menawarkan sebuah Liberating Perspective sebagai jalan tengah. Pandangan ini melihat dampak kejatuhan yang begitu dalam, akan tetapi juga memperhitungkan keindahan ciptaan dan penebusan dalam Kristus bagi perkembangan teknologi. Menurut penulis pemikiran Schuurman akan Liberating Perspective merupakan solusi terhadap problema teknologi dan kehidupan teknologis.

KATA KUNCI: teknologi, modern, masyarakat, reformational philosophy, liberating perspectives, responsible ethics. 


\section{PENGANTAR}

Alkitab mengatakan (Kristus adalah) yang utama dalam segala sesuatu (Kolose 1:19). ${ }^{1}$ Dalam hubungan beragama dan bermasyarakat, orang Kristen perlu memikirkan bagaimana keutamaan Kristus terjadi dalam segala aspek kehidupan. Salah satu aspek kehidupan yang sangat nyata dalam dunia modern adalah hubungan manusia dengan teknologi modern. ${ }^{2}$ Mulai dari kecil, manusia sudah bersentuhan dan terintegrasi dengan teknologi modern. Pengalaman kehidupan bersama teknologi modern ini mempengaruhi kesadaran manusia baik disadari

${ }^{1}$ Abraham Kuyper menggaungkan ayat ini, dalam pidatonya saat pembukaan Free University di Amsterdam, dengan kalimatnya yang terkenal: "There is not a square inch in the whole domain of our human existence over which Christ, who is Sovereign over all, does not cry, Mine!" James D. Bratt, ed., Abraham Kuyper: A Centennial Reader (Eerdmans, 1998), 488.

${ }^{2}$ Seorang anak lahir sudah bersentuhan dengan obat-obatan dan teknologi medis modern. Makanan diterimanya melalui peralatan makan yang juga merupakan hasil teknologi modern. Dalam kehidupan dia bermain dengan permainan-permainan yang juga adalah hasil perkembangan teknologi modern, seperti boneka atau mobil-mobilan plastik. Kemudian saat dia masuk ke dalam dunia pendidikan, teknologi modern kembali mewarnai kehidupannya, seperti komputer, dan sebagainya. Sistem pendidikan sendiri merupakan teknologi yang dihasilkan oleh penelitian ilmiah. Begitu pula informasi yang mereka dapatkan, diperoleh melalui teknologi modern, yakni Internet melalui komputer. Di dalam pelajaran, mereka dipersiapkan untuk menjadi bagian dari sistem produksi yang akan menghasilkan teknologi modern. Dan dalam dunia pekerjaan orang-orang akan bekerja dengan barang-barang teknologi modern maupun sistem pekerjaan yang disusun secara teknis. 
maupun tidak disadari. ${ }^{3}$ Emil Brunner dalam Gifford Lecture-nya mengatakan:

In earlier times people had hardly become conscious of [technics or technology], much less did they think of it as a problem. Today, however, it is in the front line, because - to a degree previously unheard of-technics-or shall I say technology?-determines the life of man, endangers the human character of civilisation, and even threatens the very existence of mankind. ${ }^{4}$

Dengan kesadaran ini manusia menjalani kehidupan, bergaul dengan orang lain, belajar, bekerja, dan juga berhubungan dengan Tuhan. ${ }^{5}$ Hal inilah yang sering diangkat

${ }^{3}$ Penemuan teknologi jam, misalnya, membuat waktu yang sebelumnya mengalir, menjadi detik yang dapat terhitung. Dengan waktu yang dapat terhitung mempengaruhi cara manusia melihat diri dan hubungan dengan orang lain. Efisiensi kerja dan penggunaan waktu menjadi salah satu tolak ukur yang paling penting di dalam menilai seseorang dalam dunia kerja.

${ }^{4}$ Emil Brunner, Christianity and Civilization, (Gifford Lectures, 19461948) di bawah "I: Technics";

http://www.giffordlectures.org/books/christianity-and-civilization-vol-2/itechnics-1 diakses 5-Nov-2015.

${ }^{5}$ Dewey, Staudinger, Horkheimer, Sachsse, Ihde, Tillich, Lyotard, Postman, and Rivers, as philosophers of culture, all emphasize the decisive mark that technology has made on culture, and they all, in one way or another, identify technicism as the main cause of our cultural problems. L. A. Hickman, John Dewey's Pragmatic Technology (Bloomington: Indiana University Press, 1990); Chance und Risiko der Gegenwart. Eine kritische Analyse der wissenschaftlich-technischen Welt (ed. H. Staudinger and W. Behler; 
oleh para filsuf teknologi dalam karya mereka. Pengaruh teknologi modern terhadap kesadaran manusia akan semakin besar terutama apabila penggunanya menggunakannya tanpa kewaspadaan dan kesadaran akan adanya pengaruh ini. Karena itu penting bagi orang Kristen untuk memikirkan bagaimana bersikap terhadap teknologi modern.

Apakah orang Kristen harus bersikap antitesis dengan meninggalkan kehidupan berteknologi dalam dunia modern dan menghalangi penggunaannya seperti kaum Luddites? ${ }^{6}$ Atau kalau tidak demikian, apakah itu berarti teknologi bersifat netral dan boleh digunakan dan dikembangkan semaksimal mungkin, selama penggunanya bertujuan baik? Filsafat teknologi menunjukkan bahwa penggunaan teknologi modern bukanlah tanpa dampak negatif. Kedua ketegangan ini

Paderborn: Schoningh, 1976); M. Horkheimer, Critique of Instrumental Reason (Minneapolis: Seabury, 1976); Sachsse, Anthropologie der Technik; Ihde, Existential Technics; P. Tillich, The Spiritual Situation in Our Technical Society (New York: Scribner, 1986); Lyotard, L'inhumain; N. Postman, Technopoly (New York: Knopf, 1992); T. J. Rivers, Contra Technologiam: The Crisis of Value in a Technological Age (New York: University Press of America, 1993). Egbert Schuurman, "A Confrontation with Technicism", Westminster Theological Journal 58 (1996), 73.

${ }^{6}$ Luddites adalah sekelompok penjahit tekstil di Inggris sekitar tahun 1811-17 yang melakukan protes terhadap penggunaan mesin yang menggantikan pekerjaan mereka. Protes tersebut sampai kepada penghancuran mesin-mesin tersebut. Karena itu orang-orang yang menentang penggunaan teknologi dan berusaha menyabotase barangbarang teknologi sering disebut Luddites. Penulis tidak setuju dengan pandangan tersebut karena penulis percaya teknologi merupakan bagian dari mandat budaya yang Tuhan telah berikan bagi manusia. 
seringkali menjadi pergumulan orang Kristen yang hidup sebagai pengguna maupun pengembang teknologi. Karena itu kita perlu sebuah pandangan yang tepat mengenai teknologi yang dibangun melalui pergumulan dengan Kitab Suci.

Secara umum pandangan terhadap teknologi bisa dibagi menjadi dua: pertama, mereka yang optimis terhadap teknologi,7 dan melihat bahwa teknologi merupakan jawaban dari banyak permasalahan dan jalan di masa yang akan datang; kedua, mereka yang pesimis terhadap pengaruh teknologi dan melihat bahwa, meskipun ada hal-hal baik yang dihasilkan oleh teknologi, banyak hal-hal buruk yang dibawa oleh teknologi. Meskipun ada perbedaan, karya-karya filsafat teknologi menyuarakan suara yang sama: bahwa teknologi

${ }^{7}$ Michio Kaku, misalnya, mengatakan: By 2100, our destiny is to become like the gods we once worshipped and feared ... By $2100, \ldots$ we will be able to manipulate objects with the power of our minds. Computers, silently reading our thoughts, will be able to carry out our wishes. ... With the power of biotechnology, we will create perfect bodies and extend our life spans.... It is modern science, not chanting and incantations, that will give us this power. Michio Kaku, Physics of the Future: How Science will Shape Human Destiny and our Daily Lives by 2100 (New York: Doubleday, 2011), 1011.

8 Praktisi teknologi lain, seperti Eric Schmidt, CEO pertama dari Google, Inc. berkata: Indeed, the next moment in our technological evolution promise to turn a host of popular science-fiction concepts into science facts... Such developments will join with and enhance elements of our natural world. This is our future, and these remarkable things are already beginning to take shape. That is what makes working in the technology industry so exciting today. ... it's because of what these developments will mean for the world. Eric Schmidt and Jared Cohen, The New Digital Age: Reshaping the Future of People, Nations, and Business (New York: Alfred A. Knopf, 2013), 5. 
memiliki pengaruh mendalam pada kesadaran manusia dan manusia perlu memikirkan sikap terhadap teknologi.

\section{PERBEDAAN TEKNOLOGI MODERN DAN KLASIK}

Kata 'teknologi' menurut Kamus Besar Bahasa Indonesia (KBBI) berarti "keseluruhan sarana untuk menyediakan barang-barang yang diperlukan bagi kelangsungan dan kenyamanan hidup manusia." ${ }^{9}$ Dengan kata lain, segala buatan manusia, bahkan seperti pakaian, uang, segala macam alat, baik yang kompleks maupun yang sederhana, bisa disebut sebagai teknologi. Akan tetapi artikel ini hanya akan membahas pandangan terhadap teknologi modern. Karena itu terlebih dahulu akan dijelaskan mengenai perbedaan dari teknologi modern dan teknologi klasik (pra-modern).

Secara singkat perbedaan bisa dilihat dari beberapa aspek $^{10}$. Petama, teknologi modern memiliki sifat otonomi (autonomous), bukan hanya perpanjangan (extension). Pengguna teknologi klasik (pra-modern) menggunakan teknologi sebagai sebuah 'perpanjangan tangan' (extension) dari tubuhnya saat dia berhubungan dengan alam sekelilingnya (environment). Jadi teknologi klasik (pra-modern) sangat bergantung kepada aktivitas manusia sebagai pengguna. Sedangkan di sisi lain, teknologi modern memiliki sifat yang lebih mandiri (autonomous) dan beroperasi sendiri setelah mendapatkan

\footnotetext{
${ }^{9}$ http://kbbi.web.id/teknologi diakses 11 Okt 2015.

${ }^{10}$ Diolah berdasarkan pengamatan Egbert Schuurman dalam Technology and the Future: A Philosophical Challenge hal 6-9.
} 
masukan (input) minimal dari manusia. ${ }^{11}$

Kedua, teknologi modern bersifat menantang (challengingforth) dan tidak menunggu (revealing). Teknologi klasik lebih bersifat menunggu (revealing) alam untuk memberikan tenaganya. Sedangkan teknologi modern lebih bersifat menantang (challenging-forth) atau mengondisikan (enframing) dan dengan demikian memaksa alam untuk mengeluarkan tenaganya. ${ }^{12}$

Ketiga, teknologi modern bersifat systemic, bukan situational. Teknologi klasik bersifat sementara dan hanya berhubungan dengan satu aspek kehidupan di tempat dan

${ }^{11}$ Sebagai contoh, dalam teknologi pra-modern seseorang tukang kayu memakai gergaji sebagai perpanjangan tangannya dalam tujuan memotong kayu tersebut menurut ukuran yang dikehendakinya. Sedangkan dalam teknologi modern, seorang teknisi mengoperasikan komputer dalam sebuah mesin pemotong kayu untuk memotong kayu dengan memberi input tentang dimensi potongan yang dikehendaki. Jacques Ellul mengatakan: In this respect, technique is radically different from the machine. This transformation, so obvious in modem Society, is the result of the fact that technique has become autonomous. Jacques Ellul, The Technological Society, 6.

${ }^{12}$ Sebagai contoh teknologi pra-modern, misalnya sebuah kincir air di pinggir sungai akan mendapatkan energi sesuai dengan kecepatan arus sungai yang sedang berjalan. Di sisi lain, contoh teknologi modern misalnya sebuah dam raksasa yang diletakkan di bawah air terjun dan mengurung air terjun tersebut untuk mendapatkan tenaga air terjun tersebut secara konstan tanpa harus bergantung kepada arus sungai. Heidegger mengatakan: The revealing that rules throughout modern technology has the character of a settingupon, in the sense of challenging-forth. That challenging happens in that the energy concealed in nature is unlocked, ... transformed, ... stored up, ... distributed, ... and switched about ever anew. Martin Heidegger, The Question Concerning Technology, 16. 
waktu tertentu (contextual dan situational). Sedangkan teknologi modern bersifat menyeluruh (systemic, environmental dan universal). ${ }^{13}$

Dari pembedaan di atas, teknologi dapat mulai diklasifikasikan, dan kita dapat melihat beberapa produk teknologi yang sungguh-sungguh memiliki karakteristik teknologi modern. ${ }^{14}$ Karena penulis akan memfokuskan diri dalam membahas teknologi, penggunaan kata 'teknologi' di dalam artikel ini selanjutnya akan mengacu kepada 'teknologi modern' yang perbedaannya sudah dibahas di atas.

${ }^{13}$ Sebagai contoh teknologi pra-modern, misalnya, seorang petani akan menggunakan bajak hanya pada saat dia sedang membajak di sawah. Sedangkan dalam teknologi modern, misalnya komputer, sekarang sudah menjadi bagian dari seluruh kehidupan seseorang dari rumah sampai tempat kerja, dan membentuk apa yang dapat kita kerjakan. Paul Marshall berkata: Rather, we now use technology within, among, as a part of a world which is itself shaped and made by past and present technology... We live and act now within a technical world, one which in turn shapes and limits what we do.. Paul Marshall, Is Technology out of Control in Crux 20 no. 3 S 1984, 6.

${ }^{14}$ Teknologi komputer, misalnya, bisa diklasifikasikan sebagai teknologi modern karena bersifat autonomous (berdiri sendiri, tidak bergantung sepenuhnya pada aktivitas manusia), menantang (bisa beroperasi kapanpun, tidak menunggu perlu alam), dan universal (bermain dalam segala aspek kehidupan manusia). Sedangkan teknologi seperti buku tulis dan pensil lebih bersifat klasikal, karena lebih bersifat extension (perpanjangan dari aktivitas manusia) dan situational (hanya dipakai pada saat mencatat dan membaca). 


\section{EGBERT SCHUURMAN}

Egbert Schuurman adalah seorang filsuf, dari Vrije Universiteit Amsterdam, yang pernah menjabat sebagai anggota parlemen di Belanda. Schuurman mengembangkan pemikiran filsafat reformasional dalam bidang teknologi yang diteruskan dari pemikiran Hendrik Van Riessen ${ }^{15}$.

Penulis berpendapat bahwa pemikiran Schuurman merupakan masukan yang berharga dalam membentuk pandangan Reformed terhadap teknologi modern. Pandangan ini waspada akan dampak kejatuhan dalam perkembangan teknologi, akan tetapi tetap memungkinkan keutamaan Kristus teraplikasi dalam pengembangan teknologi modern tanpa perlu bersikap antitesis. Lebih dari itu, Schuurman adalah seorang praktisi yang aktif dalam pengembangan teknologi, baik sebagai seorang insinyur maupun sebagai anggota parlemen yang membuat kebijakan-kebijakan bagi negara.

Tujuan dari artikel ini adalah untuk belajar dari Schuurman, mengenai problem kehidupan manusia di tengah dunia teknologis di zaman modern ini dan bagaimana menentukan sikap dalam hal ini. Negara berkembang, seperti Indonesia, menyambut teknologi dengan tangan terbuka, karena harapan akan perkembangan (progress). Akan tetapi kritik dan peringatan Schuurman, yang telah melihat proses

15 Peran dan pengaruh Hendrik Van Riessen dalam Filsafat reformasional dapat dilihat dalam introduksi Bernard Zylstra, dalam L. Kalsbeek, Contours of a Christian Philosophy (Wedge Pub Foundation, 1975), 26. 
perkembangan teknologi dan pengaruhnya, penting untuk dipertimbangkan.

\section{LATAR BELAKANG SCHUURMAN}

Schuurman ${ }^{16}$ pernah bekerja sebagai seorang insinyur, filsuf, politikus, dan profesor filsafat di Belanda. Dia dilahirkan tahun 1937 di Borger. Dia menjalani studi insinyur sipil di HTS di Groningen, yang dilanjutkan di Delft University of Technology sampai tahun 1963. Setelah itu dia mempelajari filsafat di Vrije Universiteit Amsterdam sampai tahun 1968. Pandangan Schuurman mengenai teknologi dilandasi oleh wawasan Kristen (Christian world-and-life view) yang diprakarsai pemikiran Abraham Kuyper ${ }^{17}$ dan dikembangkan dalam filsafat reformasional oleh Herman Dooyeweerd, dan D. H. Th. Vollenhoven. Di dalam filsafat reformasional ini Dooyeweerd dan Vollenhoven mengembangkan pemikiran sphere sovereignty dari Abraham Kuyper menjadi Philosophy of the Cosmonomic

\footnotetext{
${ }^{16}$ Biografi singkat ini disarikan dari bukunya Faith and Hope in Technology dan beberapa source internet: http://www.egbertschuurman.nl/en/, http://www.parlement.com/id/vg091lntvxzz/e_egbert_schuurman, http://www.reformationalphilosophy.org/tag/schuurman/ dan http://www.allofliferedeemed.co.uk/schuurman.htm yang diakses 19 Maret 2015.

${ }^{17}$ Di dalam Stone Lecture nya di Princeton, yang kemudian ditulis dalam buku Lectures on Calvinism, Kuyper menyatakan bagaimana Calvinism, bagi dia, menjadi sebuah life-system yang dapat menandingi modernism sebagai life-system. Abraham Kuyper, Lectures On Calvinism (Grand Rapids: Wm. B. Eerdmans, 1943), 10.
} 
Idea. Dengan kata lain, Schuurman menjadi penerus dalam pengembangan filsafat reformasional di bidang teknologi.

Setelah menyelesaikan studinya, Schuurman mengajar sebagai profesor filsafat reformasional di Technological University Delft, di Technological University Eindhoven dan di Landbouw Universiteit Wageningen selama lebih dari 40 tahun sampai tahun 2004. Tahun 1983 dia dipilih menjadi senator (Eerste Kamer) dalam parlemen Belanda (the States General). Sepanjang kariernya, Schuurman telah menerbitkan banyak buku dan publikasi seputar filsafat teknologi berdasarkan filsafat reformasional. Salah satu karyanya yang penting dalam filsafat teknologi berjudul Technology and the Future ${ }^{18}$. Dalam buku ini Schuurman membahas dua aliran pemikiran yang menyikapi teknologi modern, yakni yang dia sebut sebagai 1) transcendentalist, yakni pemikiran yang kritis dan pesimis terhadap teknologi dan 2) positivist, yang optimis terhadap teknologi. Di antara kedua arus pemikiran tersebut, Schuurman menawarkan liberating perspective terhadap teknologi.

Beberapa karyanya dalam bahasa Inggris yang akan diacu dalam artikel ini: Technology and the Future: A Philosophical Challenge (1980) ${ }^{19}$ - sebuah buku yang dikembangkannya dari

${ }^{18}$ Egbert Schuurman. Technology and the Future: a Philosophical Challenge. (Toronto: Wedge Pub Foundation, 1980). adalah sebuah buku yang dikembangkan dari disertasinya Ph.D yang dikembangkan dibawah supervisi Hendrik Van Riessen.

19 Schuurman, Technology and the Future. Buku dalam bahasa asli diterbitkan tahun 1980. Buku yang diacu oleh penulis diterjemahkan ke dalam bahasa Inggris dan dicetak ulang tahun 2009. 
disertasinya dan menjadi magnum opus-nya - lalu Reflections on the Technological Society $(1977)^{20}$, Christians in Babel (1987) ${ }^{21}$, The Technological World Picture and an Ethics of Responsibility (2005)22, Faith and Hope in Technology $(2000)^{23}$, dan juga beberapa artikel lain $^{24}$.

\section{PANDANGAN SCHUURMAN AKAN TEKNOLOGI MODERN}

Schuurman mendefinisikan teknologi sebagai aktivitas di mana manusia memberi bentuk kepada alam untuk mencapai tujuannya dengan bantuan alat. ${ }^{25}$ Jadi dengan kata lain, teknologi bukan sekadar benda atau artefak, akan tetapi

${ }^{20}$ Egbert Schuurman, Reflections On the Technological Society (Ontario, Canada: Wedge Publishing Foundation, 1977).

${ }^{21}$ Egbert Schuurman, Christians in Babel (Ontario, Paedia: 1985).

${ }^{22}$ Egbert Schuurman, The Technological World Picture and an Ethics of Responsibility: Struggles in the Ethics of Technology (Sioux Center, IA: Dordt College Press, 2005).

${ }^{23}$ Egbert Schuurman, Faith and Hope in Technology (Toronto:

Clements Publishing, 2003).

${ }^{24}$ Beberapa artikel yang akan diacu: Egbert Schuurman, “Technology in a Christian-philosophical perspective", Theology and Technology: Essays in Christian Analysis and Exegesis, ed. Carl Mitcham and Jim Groote (University Press of America, 1984); "A Confrontation with Technicism", Westminster Theological Journal 58 (1996); "Beyond the Empirical Turn: Reponsible Technology" (2000), "Philosophical and Ethical Problems of Technicism and Genetic Engineering" Techne, Electronic Journal of The society for Philosophy and Technology, vol.3, no. 1,1997.

${ }^{25}$... I will define technology initially as the activity by which people give form to nature for human ends, with the aid of tools. Technology and the Future, 5-6. 
mencakup segala kegiatan manusia yang mengubah alam, misalnya membuat pakaian, dan sebagainya, sehingga sangat dekat dengan konsep budaya. Akan tetapi artikel ini membahas mengenai teknologi modern, sehingga perlu dibedakan dengan teknologi klasik.

Serupa dengan pembedaan yang dilakukan penulis di atas, Schuurman melihat bahwa teknologi modern: 1) lebih bersifat melingkupi (environment); 2) bersifat mandiri (independent); 3) mengambil tenaga dari alam, bukan dari binatang atau manusia; 4) memproyeksikan keahlian manusia; 5) bersifat otomatis (automatic); 6) membutuhkan kerjasama (cooperation) dari banyak pihak; 7) dan abstraksi rasional (rational abstraction) ${ }^{26}$ Schuurman menyimpulkan:

Modern technology, owing to its scientific foundations, has seen a tremendous advancement. It is highly differentiated and dynamic. It has put its stamp on the whole culture, sweeping it right along with the swift pace of development. ... however, I would note that even in modern times, technological activity is and remains a human activity. This fact is decisive for proper insight into the limitations and possibilities of technology. ${ }^{27}$

Tujuan utama (grand quest) dari teknologi modern, menurut Schuurman, adalah untuk membangun sistem

26 Ibid., 6-7.

27 Ibid., 9. 
teknologis yang bisa beroperasi secara mandiri. ${ }^{28}$ Di dalam proses ini terjadi pembedaan antara tahap perancangan (designing) dan tahap pelaksanaan (execution). Karena ini juga teknologi modern memiliki struktur yang kompleks.

\section{TECHNOLOGICAL WORLD-PICTURE}

Schuurman melihat bahwa permasalahan teknologi muncul karena adanya pereduksian realita kehidupan dan absolutisasi terhadap salah satu aspek realita. Pereduksian realita ini menyebabkan munculnya technological world-picture, yakni wawasan dunia yang menekankan nilai-nilai yang dipengaruhi oleh teknologi dan mengabaikan nilai lainnya dalam ciptaan.

The norms that follow from the values of the technological world picture are effectiveness, standardization, efficiency, success, safety, reliability, and maximum profit, with little or no attention given to the cost to humanity, society, the environment, and nature. ... In summary, the first and great commandment of "technological culture" is, "Be as effective as is technically possible," and the second like unto it is, "Be as

28 The grand quest in modern technology has been to develop technological objects that can operate independently. To this end, human proficiency in forming is projected into and transferred to the technological object. Ibid., 12. 
efficient as is economically possible." 29

Dia melihat fenomena ini mulai di abad modern dalam perkembangan ilmu pengetahuan yang mulai menggantikan iman kepercayaan karena memiliki unsur iman tersendiri (faithin-science). ${ }^{30}$ Schuurman mengamati bahwa di balik belief in science tersebut sebenarnya ada belief in control yang dilandasi oleh belief in human autonomy dan berkembang dengan adanya belief in progress. $^{31}$ Sebagian besar dorongan dalam pengembangan ilmu muncul karena kepercayaan bahwa dengan mengetahui aturan alam, kita dapat mengontrol hasil sesuai dengan keinginan kita. Hal ini karena manusia memang ingin memiliki kontrol penuh akan hidupnya, dan lepas dari otoritas Tuhan. Dorongan ini tidak begitu kelihatan karena tersaru dengan adanya kepercayaan bahwa dunia sedang mengalami kemajuan, yang dinilai secara teknologis, dan itu adalah hal yang sepenuhnya baik.

${ }^{29}$ Schuurman, The Technological World Picture and an Ethics of Responsibility, 22.

${ }^{30}$ At issue is not the relation between faith and science, but the relation between the Christian faith - in which, by way of a Christian lifeand-world view, there is room for a certain view of science-and faith in science. Schuurman, Faith and Hope in Technology, 23.

31 The reason is that people seek their certainty in the logically compelling, necessary and inescapable features of science. But they are even more firmly attached to science's powers and possibilities of control. In that case, faith in science is simultaneously belief in the technical control of reality and its problems. Since people expect material progress from this belief, this belief in control is accompanied by belief in progress. Schuurman, Faith and Hope, 21. 


\section{TECHNICISM}

Wawasan dunia yang bersifat teknologis ini, membawa kepada permasalahan yang lebih dalam. Schuurman melihat problema ini sebagai technicism, yaitu sebuah pandangan manusia yang melihat dirinya sebagai otonomi yang mengontrol segala realitas. ${ }^{32}$ Technicism ini, yakni keinginan untuk mengontrol realita dengan alat dan metode teknologisilmiah (scientific-technological), adalah latar belakang rohani (spiritual background) dari kebudayaan teknologis. ${ }^{33}$ Bertolak belakang dengan Alkitab yang menunjukkan bahwa seluruh realita ciptaan datang dari Tuhan dan mendapat makna (meaning) dan tujuannya dari Tuhan. Sehingga apa yang dilakukan oleh manusia dalam technicism adalah sebuah

32 In short, technicism - or what is the same, the (implicit) ideology of technology - is the dominant spirit of the West. Technicism entails the pretension of the autonomous man to control the whole of reality: man as master seeks victory over the future; he is to have everything his way; he is to solve problems old and new, including the problems caused by technicism; and he is to guarantee material progress. Schuurman, $A$ Confrontation with Technicism, 69.

33 ... the spiritual background of modern technology and of our technological culture is technicism. Technicism reflects a fundamental attitude which seeks to control reality, to resolve all problems with the use of scientific-technological methods and tools. Technicism entails the pretense of human autonomy to control the whole of reality. Egbert Schuurman, "Philosophical and Ethical Problems of Technicism and Genetic Engineering", Techne, Electronic Journal of The society for Philosophy and Technology, vol.3, no. 1,1997. 
kepura-puraan (pretension). ${ }^{34}$ Dan ini menjadi bahaya bukan saja karena perlawanan manusia kepada Tuhan, tapi juga perkembangan teknologi akan terhambat dan menyeleweng ke arah yang destruktif. Schuurman melihat permasalahan dunia yang seringkali dilihat dari sisi ekonomi, sosial, dan budaya dapat dimengerti dengan lebih tepat pada saat kita melihatnya sebagai kritik terhadap technicism. ${ }^{35}$ Yakni keinginan manusia untuk menyelamatkan dirinya dengan usahanya sendiri melalui teknologi tanpa Allah. ${ }^{36}$

Technicism is the pretension of humans, self-declared lords and masters using the scientific-technical method of control, to bend all of reality to their will in order to solve all problems, old and new, and to guarantee increasing material prosperity and

${ }^{34}$ Reality, defined biblically, is an entity with an origin, existence, and destiny given to it by God. But modern man's technical world has no relation to meaningful creation. In other words, man pretends that his technical world is identical to total reality, reducing everything to components of a great technical whole. Schuurman, A Confrontation with Technicism, 69.

${ }^{35}$ In conclusion, I believe that a great variety of cultural problems and the cultural crisis can be better understood more satisfactorily from the standpoint of a critique of technicism than through the other approaches that are usually taken, Ibid., 71 .

${ }^{36}$ At its core, technicism wants to save human life without God. The Bible teaches us about Cain, about Lamech, about the building of the Tower of Babel, about Nebuchadnezzar, and so on. ... The possibilities of modern technology have enhanced the ideology of technology. This ideology is mainly implicit. The gravity of this situation is often concealed by the numbing effects that emanate from a sweeping material prosperity. Ibid., 74. 
progress. ${ }^{37}$

Schuurman melihat bahwa trend ini tampak jelas dari pemikiran filsafat yang bersifat teknisis. ${ }^{38}$ Mulai dari Leonardo Da Vinci (1452-1519) di zaman Renaissance sebagai bapak penemu benda-benda teknologi; Rene Descartes (1596-1650) dan Galileo Galilei (1564-1642) yang melihat ciptaan sebagai complex automatons yang dapat dimanipulasi; Francis Bacon (1561-1626) yang mengatakan "knowledge is power", dan melihat bahwa dengan teknologi kita dapat mengatasi dampak kejatuhan; Thomas Hobbes (1588-1679) seorang deist yang menganjurkan penerapan pemerintahan dan masyarakat sebagai sebuah mesin; lalu di zaman Enlightenment, Immanuel Kant (1724-1804) dengan filsafatnya yang bersifat konstruktif dan filsafat moral yang mencari bagaimana manusia didesain; Ludwig Feuerbach (1804-1872) yang membawa technisistic thinking menjadi controlled praxis, Auguste Comte (1798-1857) yang melihat bahwa proses sosial dapat dipelajari dan dikontrol dengan teknologi seperti benda mati; Karl Marx (1818-1883) yang melihat perkembangan manusia sebagai pencapaian scientific-technical control atas alam dan peningkatan kesejahteraan material, sampai kepada filsafat pragmatisme seperti William James (1842-1910) dan John Dewey (1859-1952) yang melihat dunia sebagai material yang dapat dibentuk oleh

37 Schuurman, Faith and Hope in Technology, 69.

38 Bagian yang berisi kumpulan pemikir ini diringkas dari Schuurman, Faith and Hope in Technology, 81-92. 
manusia dan solusi problema hidup melalui instrumentalism, dan juga filsafat dekonstruksi yang melihat masa lalu sebagai alat yang dapat didekonstruksi untuk keperluan kita.

Bahaya bukan terletak pada metode ataupun alat teknis, akan tetapi dalam over-estimasi dan pengharapan di dalamnya. ${ }^{39}$ Technicism ini juga mendorong penerapan teknik dalam segala aspek kehidupan dan membuat teknologi menjadi menyeluruh (environmental $)^{40}$ dan segalanya mulai bergantung kepada teknologi. ${ }^{41}$ Karena itu, pengembangan ciptaan menjadi one-dimensional $^{42}$ membawa banyak masalah yang tidak

${ }^{39}$ Backed up by the ideal of progress emerging from the Enlightenment era, modern technology soon turned into something upon which trust for the future can be built. The ideological expectation that technology can serve as the redeemer from the defects within society accompanied the rise of modern technology. Danie Strauss, Philosophy: Discipline of the Disciplines (Grand Rapids: Paideia Press / Reformational Publishing Project, 2009), 500-501.

${ }^{40}$ In modern technology, everything is connected to everything else. The result is a technological environment. Take away this technology, and our culture collapses. It has become an essential precondition for our whole life. Schuurman, The Technological World Picture and an Ethics of Responsibility, 5.

${ }^{41}$ Modern technology is beginning to penetrate and direct all of culture. The eventual result will be a "technological culture" in which technology puts a stamp on most everything and most everything becomes dependent on technology. When this dependence is connected with the economy, culture tends to become one-dimensional. Schuurman, Ethics of Responsibility, 7.

${ }^{42}$ Juga seperti yang dikemukakan oleh Marcuse, Herbert OneDimensional Man: Studies in the Ideology of Advanced Industrial Society. Boston: Beacon Press, 1991. 
disadari. ${ }^{43}$

Seringkali manusia baru mulai sadar pada saat permasalahan teknologi itu muncul dalam fenomena yang kelihatan. Beberapa fenomena yang diamati oleh Schuurman sebagai berikut. Pertama, permasalahan ekologi, baik yang berskala besar seperti global warming, penipisan ozon, perubahan iklim, dsb. ${ }^{44}$ dan juga yang berskala kecil. Misalnya, karena proses industrialisasi peternakan dan pertanian, maka tumbuhan dan tanaman dimanipulasi untuk menghasilkan hasil terbanyak. Proses ini menyebabkan genetic standardization dan hilangnya keragaman genetik dari binatang dan tanaman yang kurang produktif. ${ }^{45}$ Terlebih lagi karena pandangan umum dalam bioteknologi melihat bahwa manipulasi ini hanya akan membawa kebaikan kepada alam dan kesejahteraan

43 Preoccupation with one thing inevitably decreases one's sensitivity to others. As data and information multiply, their cumulative meaning usually decreases. Contact increase, but their significance is blurred. Information abounds while wisdom wanes and understanding hardly scratches the surface. Internet use may be on the rise, but spirituality is on the decline. Ethics of Responsibility, 17.

44 The development of technology has always, in a sense, been ambiguous: besides advantage there were disadavantages. ... the development of modern technology seems inescapable and has such global consequences as the depletion of the ozone layer, climate chages, the melting of the ice at the South Pole, and the rising sea level. Schuurman, Faith and Hope in Technology, 94.

45 The consistent artificial refinement of these plants to produce higher yields has another side, namely, the danger of making the genetic profile uniform. ... it results in genetic erosion. ... on account of the uniform genetic profile and hence the limited genetic diversity, resistance to unknown diseases has decreased. Ibid., 103. 
manusia.

Kedua, permasalahan sosial, seperti pergeseran tenaga kerja dari mereka yang kurang terdidik untuk berintegrasi dalam dunia teknologi. Juga adanya perubahan cara pandang terhadap manusia yang berfokus kepada fungsi dan efisiensinya dalam mendukung dunia teknologi. Schuurman menyebutnya sebagai proses functionalization, di mana teknologi dan ekonomi menyeleksi dan mengangkat orangorang yang lebih functional dalam mendukung operasional. Karena itu juga terjadi flexibilization ${ }^{46}$, yakni pengarahan individu kepada fungsi yang dibutuhkan tanpa mempertimbangkan keadaan asal mereka. Selain itu bertambah pula individualisme dan disintegrasi ikatan sosial, karena pertambahan jumlah kemakmuran material tiap individu. ${ }^{47}$

Ketiga, masalah kekurangan (deficiency) dan ketidakadilan (injustice) dalam pengembangan aspek ciptaan yang lain. ${ }^{48}$

${ }^{46}$ This dynamization and functionalization, jointly called "flexibilization," are currently held in high esteem. In reality we are dealing here with a level of technicization that is threatening to our humanity; human beings threaten to reduce to their technical functioning. Ibid., 111.

47 ... the material prosperity which people gained has made many of them economically independent of each other. This development leads to the break-up of social ties, resulting in such well-known phenomena as social disintegration and all kinds of alienation. Ibid., 95.

${ }_{48}$ Conceptions about the cosmos are often very limited because justice is not being done to the multifaceted depth and breadth of reality. Reality is often reduced to the world that science and technology aim to control-to a positivistic cosmology, a view of the cosmos to which technology is the key. This lopsided take on the world does not do justice to the many-sided dimensions and coherence of reality in its fullness and pays 
Realita kehidupan yang diciptakan oleh Tuhan memiliki kekayaan aspek dan multi-dimensi yang perlu dikembangkan. Akan tetapi manusia, yang menolak untuk melihat Tuhan sebagai sumber, menjadikan perkembangan teknologi mengarah kepada realita di mana teknologi mengunci perkembangan ciptaan. Akibat fokus kepada satu aspek atau satu dimensi, pengembangan teknologi menyebabkan ketimpangan dalam pengembangan aspek yang lain. ${ }^{49}$

\section{KEBUDAYAAN BABEL}

Permasalahan technicism ini, di mana manusia melihat dirinya sebagai otonomi yang mengontrol realita dengan teknologi, ${ }^{50}$ telah memengaruhi budaya manusia modern yang kita hidupi. Schuurman mengasosiasikan budaya ini dengan kebudayaan Babel yang berusaha untuk mencapai keselamatan

no attention to its dependence on and orientation with respect to its divine Origin, no heed to transcendental direction of everything. Schuurman, Technological World Picture and Ethics of Responsibility, 29.

${ }^{49}$ Misalnya, fokus kepada aspek historis membuat orang berlomba membuat teknologi yang lebih canggih tanpa memperhitungkan dampaknya kepada alam maupun apakah hal itu sungguh dibutuhkan oleh masyarakat.

${ }^{50}$ Science and technology are often blamed for the mess we are in, but I assert that this is a devastating misunderstanding. The origin of the problem is man. Man has come to see himself as the Alpha and Omega. ... Since access to a living God has been closed, mankind has put hope in what science and technology can make of the future. Schuurman, Christians in Babel, 24. 
dengan usahanya sendiri (Kej. 11). ${ }^{51}$ Dengan niat ini, science, dimungkinkan oleh teknologi, menjadi alat untuk membuka jalan keselamatan dan pandangan eskatologi Kristen tidak lagi memiliki tempat. ${ }^{52}$

Kebudayaan Babel ini juga disebabkan oleh pereduksian realita ke dalam scientific and technological model, yang Schuurman jabarkan sebagai berikut: ${ }^{53} 1$ ) ilmu (science) semakin otonom dan mandiri; 2) ilmu dipakai menjadi alat untuk manusia mengontrol alam; 3) semangat kontrol ini datang dari keinginan religius manusia untuk membebaskan diri; 4) ide ini dimulai dalam lingkungan para ilmuwan dan menyebar

${ }^{51}$ From a biblical point of view our culture can probably be identified as Babylonian. Here man worships various gods as he builds whatever his science and technology enable him to build. Schuurman, Christians in Babel, 8.

${ }^{52}$ Knowledge and science became the tools with which man would clear a path into the future. That path began to open when modern technology began to develop. Gradually the idea took hold that both man and the world could be brought to fulfillment through the use of science and technology. And Christian eschatology steadily retreated in the face of technological expectations of redemption. Ibid., 19.

53 (1) Science keeps becoming more independent, autonomous, and self-sufficient. ... (2) Science is also being called on to be the main instrument of human control over the world.... (3) This concentration of control comes from man's religious yearning to realize and liberate himself. ... (4) ... once the material prosperity on the industrial revolution had become available to the masses, the masses accepted progress as an article of faith. ... (5) ... through [economic and political] forces could large scale development have taken place. ... (6) Because the religious dynamic of the world is apostate, culture will become more and more secular. Schuurman, Christians in Babel, 29-31. 
kepada massa dengan munculnya kemakmuran materi akibat revolusi industri; 5) pengembangan teknologi dalam skala besar ini ditopang dengan kekuatan ekonomi dan politik yang membutuhkannya; 6) dan kebudayaan menjadi semakin sekuler dan tak bertuhan (apostat).

Di dalam keadaan ini, realita (world of experience ${ }^{54}$ ) dirampas dari maknanya sebagai ciptaan yang kaya akan meaning (richly differentiated, deeply alive entity borne up by the Word of $\mathrm{God}^{55}$ ) menjadi model scientific and technological dengan pretended autonomy-nya. Teknologi dikembangkan dengan nafsu akan kepuasan materi (insatiable yearning for material prosperity) tanpa adanya norma (anormativity) ${ }^{56}$ sehingga terjadi overdevelopment dan exploitation. Kemudian, sama seperti Babel,

${ }^{54}$ What do we mean by "our world of experience"? That world is the world in which we live, hope, suffer and struggle; it is the world in which we see things simply, in which we feel and love; it is also the world of faith and trust; in fact, faith and trust are the pivotal point of that world. This world of experience is original and primary; it cannot be fully comprehended; it is complex, concrete, full, richly varied and profoundly inscrutable. Every human activity and its meaning - science and technology and their meaning, belong to this world. Ibid., 32-33.

${ }^{55} \mathrm{In}$ this way of thinking, reality is robbed of its meaning. Reality is no longer creation, a richly differentiated, deeply alive entity borne up by the Word of God. Instead, man "creates" a world impelled by a technological dynamic, and then tries to accept it as the real world, though it is devoid of meaning. Ibid., 31.

56 Thus, both inside and outside the process of scientifictechnological development, we find that the current problems and perils are brought on by people who develop and build without norms. The anormativity of their production is the result of their pretension that they, not God, determine the development of science and technology. Ibid., 36. 
perkembangan kebudayaan ini akan mengarah dan menyatu kepada sebuah kekuatan global (one single mobilized global power) yang tidak lagi dapat dikontrol oleh manusia, tapi mengontrol manusia. ${ }^{57}$

\section{SOLUSI TERHADAP PERMASALAHAN TEKNOLOGI}

Schuurman memberikan beberapa solusi terhadap permasalahan technicism ini. Pertama, Schuurman melihat pentingnya membangun kesadaran orang Kristen terhadap adanya technicistic mind ini. Schuurman melihat bahwa kebanyakan orang Kristen tidak menyadari adanya pemikiran technicism ini. Tanpa kesadaran ini, usaha orang Kristen hanya akan mengkristenkan pandangan sekuler ini, dan mereka tidak mampu memberikan jawaban, resistansi ataupun arahan yang tepat bagi kehidupan teknologis ini. ${ }^{58}$ Orang Kristen harus

${ }^{57}$ Man will be imprisoned by everexpanding forces which will ultimately be united and mobilized in one single global power. That is, the future sketched by the evolutionary futurologists will be a technological society in which everyone and everything will be reduced to component parts of one large, comprehensive, totalitarian system. Within that system, a human being will be a cog, fully interchangeable and replaceable. Ibid., 12 .

${ }^{58}$ Not seeing the background of our times in religious terms, Christians are perhaps trying to Christianize the secularized ideas of the Enlightenment. In reality they have closed their eyes to the central fact that human autonomy is concentrated in the scientific-technological control of everything. In any case, they seem unable to offer significant resistance against the unrestricted scientific-technological manipulation of reality. ... If Christians are not aware of this religious component, they really lack the capacity to offer an adequate critique of our technological culture and to 
menyadari pengaruh dosa dalam kehausan ilmu dan teknologi akan kontrol. Kita perlu mengembangkan kebudayaan dunia ini dengan kesadaran bahwa kita adalah "warga kerajaan Surga". ${ }^{59}$ Selain itu orang Kristen juga perlu memiliki insight terhadap kuasa yang bekerja di dalam dunia dengan segala keterkaitannya sehingga kita dapat memberikan pandangan yang membebaskan (liberating perspective). ${ }^{60}$

Kedua, Schuurman mengusulkan etika tanggung jawab (responsible ethics) dengan dasar kasih kepada Tuhan dan ciptaan dalam mengembangkan teknologi. ${ }^{61}$ Setiap 'aktor'

indicate the right, reforming normative direction to go. Schuurman, $A$ Confrontation, 75 .

${ }_{59}$ Moreover, awareness of sin and its corrosive effects in culture should remind Christians "not to love the world ..." (1 John 2:15-17). Developing culture in the realization that we are "citizens of a kingdom of heaven" (Phil 3:20) indicates that there is another cultural orientation than that of the scientific-technical ideal of control. Schuurman, Faith and Hope, 157.

${ }^{60}$ In order to live in the power and light of that liberating perspective, and on that basis to play our responsible role in culture, we must know the history of our culture and have insight into the spiritual forces at work in it. We also need to have some insight into the development of the powers and their interconnectedness. Schuurman, Faith and Hope, 162.

${ }^{61} \mathrm{I}$ believe an ethics of responsibility is the most appropriate approach for an ethics of technology. ... Everyone involved in scientifictechnological development not only carries accountability, but must also answer for his actions. In other words, everyone must indicate on the grounds of which cultural picture, which motives, values, principles, norms he acted and made his contribution in the scientific-technological events. ... the 'actors' must be aware of the positive scope of their action in or with technology. Schuurman, The Ethics of Technology. Online source 
dalam pengembangan teknologi harus menyatakan landasan keputusannya dalam pengembangan teknologi. Dengan kesadaran bahwa manusia ada di dalam dunia untuk bekerja di hadapan Tuhan (Coram Deo), maka tindakan budaya akan memiliki konten yang berbeda. ${ }^{62}$ Motivasi pendorong bukanlah kekuasaan (power) tapi kasih (love), yang akan mendorong perkembangan (divergence) dunia ciptaan. Dalam konteks ini, science akan menjadi pencarian akan wisdom dan teknologi menjadi pembangunan dan pemeliharaan (building and preservation ${ }^{63}$. Kebudayaan dikerjakan sebagai seorang yang mewakili Tuhan (steward) dan melihat alam sebagai sebuah taman yang dipercayakan oleh Tuhan untuk dijaga dan

http://www3.nd.edu/ ecoltheo/text_schuurman.htm diakses tanggal $15 \mathrm{Agt}$ 2015.

62 When one proceeds from a recognition that man is meant to do his work in culture coram Deo, before the face of God, and guided in doing so by the normative character of the dynamics of creation - and that man is not, as in technicism, himself the center of reality, but in his cultural activities should deny himself in love towards God and his neighbor - then the motives for the various cultural activities receive a different content. Instead of the central motive of power, in which everything man does revolves about himself, we have the central motive of love, which produces divergence in man's various cultural activities. Schuurman, A Confrontation, 78 .

${ }^{63}$ In the place of power as the central motive in which people revolve around themselves, the central motive of love yields a divergency of various cultural activities. This implies that in science the goal ought to be growth in wisdom; in technology, construction and preservation; in agriculture, harvesting and tending and keeping; in economics, stewardship; and in politics, the administration and advancement of justice and public righteousness.

Schuurman, Faith and Hope, 172. 
dikembangkan (garden metaphor). ${ }^{64}$ Dengan melihat alam, bukan sebagai mesin yang harus dikontrol secara scientific dan technical, akan tetapi sebagai hadiah dan titipan, maka ada ruang untuk ucapan syukur dan pemeliharaan akan ciptaan ini. ${ }^{65}$

Ketiga, Schuurman melihat perkembangan teknologi perlu memenuhi beberapa prinsip normatif yang saling terkait (interrelated normative principles). Dalam bagian ini dia mengembangkannya dari Cosmonomic Philosophy dari pemikiran Dooyeweerd. Problem teknologi terjadi karena pereduksian realita kepada satu aspek. Karena itu perlu ada prinsip normatif yang meliputi pertimbangan dari berbagai aspek yang lain, misalnya: 1) cultural-historical norm ${ }^{66}$ yakni

${ }^{64}$ The garden metaphor conveys our human connectedness with the whole of creation and our dependence on it. The mutual relations in the picture of the garden guarantee protection and preservation in our tilling and harvesting. That picture of reality as a garden implies a different orientation toward life and culture. ... Concerned for everything that lives, people will direct their attention toward providing for the necessities of life, the prevention and relief of suffering, and the preservation of the diversity of the life forms present in the plant and animal world. Schuurman, Faith and Hope, 166.

$65 \ldots$ if we start with the idea that reality is a gift to us, there is room first of all for gratitude, for the care and maintenance of God's creation. Control by means of science and technology plays a subordinate role.... Technology, economics and ecology then represent a sustainable balanced set of relations. That is the most important implication of the garden metaphor. Ibid., 170.

${ }^{66}$ The cultural-historical norm is that of differentiation and integration, of continuity and discontinuity, of centralization and decentralization, of large-scale and small-scale dimensionality, of uniformity 
pengembangan yang beragam; 2) lingual and social norm ${ }^{67}$ yakni pengomunikasian intensi teknologi; 3) economic norm $^{68}$ atau efisiensi yang seimbang; 4) norm of harmony ${ }^{69}$ yakni pengadaptasian teknologi kepada kehidupan secara harmonis; 5) norm of justice ${ }^{70}$ yakni kewaspadaan terhadap dampak ketidakadilan dalam penerapan teknologi baru; 6) ethical norm of care and love $e^{71}$ yakni kasih yang ditujukan pada segala ciptaan;

and multiformity... When the scientific method of design and technology is directed to one side of this norm to the neglect of the other, then technology is put on a one-sided and ultimately dangerous track. ... Satisfying both components of the cultural-historical norm offers a more balanced development of technology. Schuurman, Faith and Hope, 195.

${ }^{67}$ The lingual norm is that of information, clarity, or openness. This means that information must be provided about every technical innovation in a clear public manner. It is only under this condition that those who are active in technology or consumers of its products can carry out their specific responsibility in evaluation and decision-making. Ibid., 196.

${ }^{68}$ The economic norm of stewardship that manifests itself in technology as efficiency must be honored but never one-sidedly so. ... under the influence of technicism has been narrowed down too much by betaefficiency and in which goods that can only be measured in monetary terms determine what value is. Ibid., 197.

${ }^{69}$ This norm implies, for instance, that new technical possibilities may never be introduced in a revolutionary fashion, something that could further entail social unrest and the loss of public support. ... The norm of harmony also requires that technology must be adapted to human beings instead of the reverse. Ibid., 197-98.

${ }^{70}$ In responding to the juridical norm we offer resistance to any possible injustice the development of technology may bring with it. Ibid., 198.

${ }^{71}$ I have in mind the care and love for everything that has to do with technology and by implication for our many neighbors, far and near, and for our "natural" fellow creatures. ... If this norm is not honored in all 
dan 7) pistical norm ${ }^{72}$ yakni kepercayaan (trust) kepada perkembangan teknologi yang seimbang dan kebergantungan kepada Tuhan, serta penolakan akan kepercayaan kepada ilmu dan teknologi. Dengan mengikuti prinsip normatif ini, pengembangan teknologi perlu mengarah kepada pembedaan (differentiation or diversity) dan menolak dominasi effectivity and efficiency. ${ }^{73}$ Mengenai prinsip normatif ini akan dijabarkan lebih lanjut pada bagian LIBERATING PERSPECTIVE.

Keempat, orang Kristen yang hidup dalam dunia teknologis dipanggil untuk menyelidiki ${ }^{74}$ dan menyatakan

directions, human beings become increasingly alienated from their work. Ibid., 199.

72 ... when people accept and operate according to the framework of norms, sketched above, as a guide for responsible development of technology, technology will be safe... cultural problems will not become intolerable or insurmountable. That is due to the transcendental direction of the norm of faith, namely, the acknowledgement that nothing in the world, as a creature, stands on its own, but is dependent upon the Creator and ought to be directed to him.... faithful allegiance to technology is the background for the many problems that technicalization calls for.Schuurman, A Confrontation, 81.

${ }^{73}$ Effectivity and efficiency are not the most important elements. In the first place there ought to be love, righteousness, justice, service, readiness to make sacrifices, mercifulness, and thankfulness. Schuurman, $A$ Confrontation, 83.

${ }^{74}$ If Christians had more insight into what was really going on in the world they would be misled less easily by the world's motive. An understanding of the world should be the basis for their apologetics, especially when they attempt principled action in cultural activities. In our present culture which is tending toward nihilism, it seems that Christians are all too willing to choose either for technocracy or revolution. Schuurman, Christians in Babel, 47. 
pengaruh kejatuhan di dalam perkembangan teknologi. Hal ini mungkin akan mengasingkan mereka dari dunia dan mengurangi kenyamanan, tapi kita dipanggil sebagai musafir (sojourner) yang menanggung salib (crossbearer)..$^{75}$ Peperangan dengan pemikiran technicist ini perlu dikerjakan dengan iman (full armor of faith in the One who holds all the power in heaven and on earth). Motif kontrol dan otonomi harus diganti dengan motif kasih kepada Tuhan dan sesama, sehingga baik politik, ekonomi, science dan teknologi berada pada tempatnya. ${ }^{76}$

Kelima, Schuurman melihat bahwa Tuhan sendiri telah bekerja dan Kerajaan Allah yang sudah dihadirkan dalam dunia ini tidak dapat dihentikan oleh technicism ini. ${ }^{77}$ Oleh karena itu orang Kristen tidak mengejar terjadinya perubahan

${ }^{75}$ Removing ourselves from the Babel motif and speaking against it will put the Christian into a position of sojourner and crossbearer. Schuurman, Christians in Babel, 45.

${ }^{76}$ Practical political results of such love would mean that man gives up his lust for power and seeks to promote justice and righteousness. For the economy, love means that man is no longer driven by an absolutized profit motive but instead exercises responsible stewardship. For science, love means that knowledge is no longer raw power, but that it serves the interest of wisdom. We must come to see that science and technology can be humanity's helpful servants, rather than our tyrannical masters. Schuurman, Christians in Babel, 48-49.

${ }_{77}$ It is a constant consolation to know that man on his own and by himself cannot negate this meaning of creation, the kingdom of God. On the contrary, the fact that the kingdom of God is already on the way means that at any moment people may be converted and led once again to seek the kingdom-even in a technological society. Schuurman, A Confrontation, 83. 
besar yang revolusioner yang bersifat global ${ }^{78}$, tapi percaya bahwa hal tersebut akan dikerjakan oleh Tuhan. ${ }^{79}$ Pengembangan teknologi perlu mengalami desentralisasi sehingga segala aspek ciptaan dapat terlayani. ${ }^{80}$ Kita bertanggung jawab akan hal-hal kecil yang ada di hadapan kita, dan pada akhirnya kita akan melihat bagaimana Tuhan memakai hal-hal tersebut dalam kerajaan-Nya. ${ }^{81}$ Itulah pengharapan yang dimiliki oleh orang Kristen di dalam

${ }^{78}$ For this reason, the personal cultural endeavors should not be forgotten, for it is in those areas that cultural reformation must begin. We often think in global dimensions and analyze our culture as part of a global culture, but the smaller cultural endeavors is where we must begin. Schuurman, Christians in Babel, 52.

${ }^{79}$ The perspective of the kingdom of God offers hope and confidence that things will turn out well with creation. Since that perspective is far from Utopian, we too must seek it in responsible freedom. Of course, we will not be able to save and heal culture ourselves. God himself will do that when on the last day he intervenes and makes all things new. Schuurman, Faith and Hope, 204.

80 ... with a view to a healthy future, we must insist that what is needed is a creative technology, one with room for invention and innovation, a technology that is economically productive, accommodating to ecology and culture, socially just, and personally and communally fulfilling. Such technology could even be integrated with computers or the Internet because it would allow for a good degree of decentralization rather than the concentration of power. Schuurman, Technological World Picture and Ethics of Responsibility, 53.

${ }^{81}$ Amidst a centralizing and grand-scale technological culture with all its power, Christians will have to seek the decentralizing small-scale direction of love, of justice, of service, of the willingness to make sacrifices, of mercy, and of gratitude. These are the missing words missing in the vocabulary of the ideology of technology. Schuurman, Faith and Hope, 202. 
menghadapi permasalahan teknologi.

\section{LIBERATING PERSPECTIVE}

Pada bagian akhir buku Technology and the Future, Schuurman memberikan beberapa pandangan mengenai liberating perspective bagi pengembangan teknologi. Berbeda dari para transcendentalist ${ }^{82}$, Schuurman melihat bahwa masih ada harapan bagi pengembangan teknologi. Para pemikir transcendentalist gagal melihat bahwa kelanjutan perkembangan teknologi dapat dicegah dan ada kemungkinan untuk sudut pandang yang baru. Mereka gagal melihat otonomi manusia di balik otonomi teknologi sehingga mereka tidak melakukan analisis kritis dan akhirnya melihat teknologi sebagai sesuatu yang berlawanan dengan kebebasan. ${ }^{83}$ Bagi Schuurman, pengabsolut-an pemikiran teknologis-ilmiah (absolutization of technological-scientific) inilah yang menjadi sumber pengembangan teknologi yang keliru. Dan hal ini sama bahayanya dengan peng-absolut-an kebebasan (absolutization of

82 Pemikir-pemikir yang pesimis terhadap perkembangan teknologi dan melihat bahwa masa depan yang berarti (meaningful future) tidak membutuhkan teknologi.

${ }^{83}$ Although the transcendentalists reject the imperialism of technology because its superior power banishes human freedom, they do not see through the autonomy of technology and perceive that it is an illusion. Because they fail to undertake a critical examination of this autonomy, they are never in a position to indicate a perspective for the future in which technology can assume a meaningful place of its own. Technology and freedom exclude one another, according to them. Schuurman, Technology and the Future, 376. 
freedom). ${ }^{84}$ Karena pandangan mereka memiliki worldview humanis yang tertutup, maka mereka tidak berhasil menawarkan pandangan masa depan yang membebaskan di mana teknologi memiliki tempat dan kebebasan manusia tidak terancam ataupun dibuat absolut. ${ }^{85}$

Di sinilah Schuurman memperlihatkan filsafat Kristen sebagai jalan keluar yang ditawarkannya. Masalah pengembangan teknologi terletak pada manusia yang mengira dia berotonomi (human pretension to autonomy). Untuk mendapatkan pandangan yang bermakna bagi pengembangan teknologi, kita harus menyelidiki dan menolak otonomi itu. Di sinilah filsuf mengambil peranan penting untuk memperoleh pandangan yang cukup dalam mengenai teknologi dan menyelidiki interaksi antara filsafat dan teknologi. ${ }^{86}$ Filsafat teknologi harus dikaitkan dengan agama (religion) yang melihat

${ }^{84}$ The absolutization of technological-scientific thought can no more be carried through to completeness than can the absolutization of freedom. Ibid., 377.

${ }^{85}$ It seems to me that the positivists and the transcendentalists, because of their closed humanistic worldview, are not really able to offer a perspective for the future in which science and technology have a legitimate place and in which human freedom is neither excluded nor made absolute. Ibid., 378.

${ }^{86} \mathrm{~A}$ knowledge of technology and philosophy in their mutual interaction is essential to any effort to arrive at a structural analysis of modern technology. ... philosophers should pay more attention "to what really goes on in engineering and technology", and that a philosophy of technology ought to be "an empirically informed philosophy of technology". Egbert Schuurman, "Beyond Empirical Turn: Responsible Technology". Paper presented in University of Technology Delft; Delft, NL. 
bahwa realita adalah ciptaan Tuhan dan segala hal dalam ciptaan saling terkait (mutual relations) dan diarahkan kepada akhir yang berpusat kepada-Nya. ${ }^{87}$

A philosophy led by the springs of Christian faith, which is a liberating, saving faith (saved from the delusion of selfsufficiency, and therefore free to serve God), will be serviceable in indicating a meaningful, liberating, normative perspective for technological development. ... Being busy with technology should mean being busy serving God. This requires the rejection of every form of autonomy and the acceptance of the status of the bond-servant. ${ }^{88}$

Untuk menjaga arah pengembangan teknologi, Schuurman menjelaskan beberapa basis dari liberating perspective ini, yakni: 1) meaning-character of reality; 2) meaning-dynamis as normativity; 3) freedom in responsibility; 4) dynamic and dialectic; dan 5) future as progression.

Pertama, mengenai Meaning-character of Reality. Di dalam filsafat reformational ada sebuah konsep penting mengenai

${ }^{87}$ I believe that autonomy must be rejected in principle, whatever its form. As I see it, philosophy can be servicable in indicating a meaningful perspective for technological development only when it is anchored in religion, a religion in which it is confessed that reality is a creation of God, that God is the Origin of all things, that He binds the creation to His laws, and that the history of created reality, in which the mutual relations and coherence of all things are fixed, is led, controlled, and brought to its consummation by Him. Schuurman, Technology and the Future, 379.

${ }^{88}$ Ibid., 379. 
being-as-meaning. Konsep ini melihat bahwa keberadaan segala realita bergantung kepada Allah sebagai pencipta. ${ }^{89}$ Di dalam being-as-meaning ada keragaman yang luar biasa yang dapat dilihat dari berbagai macam entitas dan aspek dari entitas tersebut. Namun keragaman ini memiliki koherensi (coherence of meaning) dan menikmati kepenuhan (fullness of meaning) dalam relasi dengan Tuhan sebagai sumber (Origin of all meaning)..$^{90}$ Tugas filsafat Kristen, menurut Schuurman, adalah mendengarkan (listening) bagaimana kepenuhan dalam keragaman ini terjadi dalam hubungannya dengan sumbernya, dan dari sana memperoleh bijaksana untuk berespons. ${ }^{91}$

Kedua, mengenai meaning-dynamis as normativity. Manusia sebagai mahkota ciptaan harus mengambil pilihan akan arah (choice of direction) yang bersifat religius, yakni kepada Allah

${ }^{89}$ In the reformational philosophy, the idea of the meaning-character of reality or of "being-as-meaning" occupies a central place. What is meant by this is that everything is created, that everything is dependent for its existence upon God the Creator as the Origin, and that everything finds its destination in the Origin. All things are from, through, and to God. Ibid., 380 .

${ }^{90}$ In being-as-meaning there is diversity of meaning so immense that it defies description. This is to be observed in the great number of entities (such as things, plants, animals, people, facts, and events) and in the diverse modes of being, the aspects of the entities. ... Every variety of meaning points beyond itself and refers to all the remaining being-as-meaning. All being-as-meaning is embraced by history as the dynamic coherence of meaning. This coherence is then concentrated in the fullness of meaning, the Radix or source of power of all meaning. Ibid., 381.

${ }^{91}$ Christian philosophy is, first of all, listening. In this listening, wisdom grows and enables one to respond to the problems of complex, structured reality. Ibid., 382. 
atau melawan Allah. ${ }^{92}$ Pilihan ini memengaruhi aktivitas teknologi yang dikerjakan oleh manusia. Apabila diarahkan dengan benar, maka setiap aktivitas teknologi yang kita kerjakan akan mengarah kepada disclosure of meaning. Sebaliknya, apabila diarahkan kepada perlawanan akan meaning-dynamis, manusia hanya mengalami pretensi namun sebenarnya mengunci pengembangan teknologi. ${ }^{93}$

Ketiga, mengenai Freedom in Responsibility. Pada saat manusia taat kepada meaning-dynamis, dan menerima tanggung jawabnya sebagai bagian dari meaning-disclosure, dia mendapatkan kebebasannya (freedom). Kebebasan adalah sebuah konsep yang membatasi (limiting concept), yakni kebebasan dalam tanggung jawab. ${ }^{94}$ Schuurman membedakan

92 In history humankind must make a radical choice of direction. This choice is religious in nature. This is to say that humanity, as full, total humanity, must direct itself to God, an act which has become possible again through Jesus Christ, and that in this directedness to God humanity lets itself be led in history by the meaning-dynamis. Ibid., 382.

93 The direction of technological-scientific thought and of the consequent development of technology is guided, at bottom, by the religious choice and conviction of humanity. When this choice and conviction are nourished by attentiveness to the meaning-dynamis, every technological activity can help to disclose meaning, and technological-scientific thought can render its meaningful service. However, when technological thought and activity are set against the meaning-dynamis from the beginning, humanity may maintain a pretense of opening up a meaningful future, but its resistance means (as is brought to light, for example, in the absolutization of technological thought) the actual sealing off and locking up of meaning. Ibid., 383.

94 Obedience to the meaning-dynamis, which implies acknowledgment of the responsibility of humanity for the disclosure of the 
dua macam kebebasan: 1) religious freedom, yakni kebebasan arah hati yang menuju atau berlawan dari Tuhan; dan 2) modal freedom, yakni kebebasan dalam memilih secara bertanggung jawab dari sekian banyaknya pilihan dalam sebuah keadaan, yang semuanya memenuhi modal meaning. ${ }^{95}$

Keempat, mengenai Dynamic and Dialectic. Tergantung respon manusia kepada meaning-dynamis tadi, baik tunduk ataupun menolak, manusia dibawa kepada keadaan dialektik. Apabila manusia tunduk, maka terjadilah meaning-disclosure yang harmonis. Sebaliknya, penolakan akan menyebabkan adanya satu aspek yang ditonjolkan, memiliki pretensi otonomi, mengambil alih posisi Tuhan dan menghalangi pengembangan ciptaan (meaning-disturbance) meskipun perkembangan ciptaan tetap terjadi secara tidak lengkap. ${ }^{96} \mathrm{Di}$

meaning of the creation, at the same time signifies freedom.... Freedom is a limiting concept, and the problem of freedom lies at the frontiers of human thought. We can say, in any case, that freedom is freedom in responsibility, that humanity is called to freedom, and that freedom is a being free from every kind of autonomy and being free for the service to which God calls people in Jesus Christ. Ibid., 384.

${ }^{95}$ Modal freedom is not the choice between right and wrong, it is responsible choice from among a multitude of possibilities in a certain situation, all of which satisfy the modal meaning by which the situation is qualified. Ibid., 385.

${ }^{96}$ Taken up in history and driven by the meaning-dynamis, humanity is brought into confrontation with the choice either to submit to the meaning-dynamis or to resist it. Submission signifies that people understand and accept in their task as cultural formers. This is the most fundamental prerequisite for a harmonious, dynamic disclosure of the meaning of reality. Radical resistance implies that some creational given is taken, elevated, and made the basic denominator of all meaning. Ibid., 385. 
dalam budaya modern, pemikiran teknologis-ilmiah (technological-scientific) telah menjadi absolut dan akhirnya menghancurkan kebebasan sehingga terjadi dialektik antara hukum dan kebebasan di dalam ciptaan. ${ }^{97}$

Kelima, mengenai the Future as Progression. Sepanjang sejarah, ada dua hal yang terjadi: 1) disclosure of meaning, yakni perkembangan makna dalam ciptaan, dan 2) resistansi terhadap arah perkembangan tersebut. Manusia, di dalam dosa, menolak meaning-dynamis sehingga menghalangi meaningdisclosure dan menyebabkan meaning-disturbance. Namun, saat manusia menaruh dirinya di bawah meaning-dynamis, maka akan terjadi pertumbuhan (progression), di mana manusia tunduk kepada prinsip normatif dan mengerjakan dan situasi konkret masing-masing. (Progress yang dimaksud oleh Schuurman lebih bersifat pertumbuhan ketimbang sekadar pertambahan ${ }^{98}$ ). Manusia tidak dapat menentukan tujuan

${ }_{97}$ When humanity fails to submit radically and integrally to the Radix of all meaning and to the meaning-dynamis of the creation, that is, when it fails to let itself be guided by the norms for the development of culture, when in pretended autonomy it sets its own laws and goes its own way in conformity with these laws, then the original dynamic of the creation turns into an original dialectic within the creation -- with consequences which, despite the fictions being perpetrated, can only prove disastrous. Ibid., 386.

${ }_{98}$ Progress, it seems to me, should be construed not in the sense of advancement or improvement (vooruitgang) but in the sense of progression (voortgang). The former construction leads all too easily to the notion of an immanent meaning or immanent consummation of history. In addition to the tensions arising from the dialectic as sketched here, the groaning and travail of the whole creation (Romans 8:22) as a result of the fall into sin will 
akhirnya sendiri, tapi melihat kepada masa depan yang pasti di dalam Kerajaan Allah yang dikerjakan oleh Kristus. ${ }^{99}$

\section{MEANING DISRUPTION}

Di atas kita melihat bahwa pada saat manusia tidak tunduk kepada meaning-dynamis, maka akan terjadi meaningdisturbance atau meaning-disruption dalam teknologi. Berkaitan dengan meaning-disruption ini, Schuurman melihat ada beberapa motif pemikiran yang bekerja di dalamnya: 1) pemikiran bahwa teknologi adalah applied science; 2) ide bahwa teknologi adalah alat dari kehidupan ekonomi (handmaiden of economic life); 3) keyakinan bahwa teknologi adalah instrumen yang netral (neutral instrument); 4) pandangan yang mengkaitkan teknologi dengan keinginan akan kuasa (will to power); dan 5) dorongan untuk mengembangkan teknologi bagi kepentingan teknologi semata (technology for technology's sake $)^{100}$.

continue to characterize history until its consummation, even if that groaning points to -- and is thus a sign of -- the total redemption and disclosure of creation. Ibid., 464.

99 There are two things that we may not forget. The first is that humanity, regardless of its self-chosen objectives, is subject to the future that has been set by Jesus Christ -- the Kingdom of God. We saw that the dialectic borrows its very possibilities from the meaning-dynamis, if only to resist it, but that it is accordingly brought to judgment. The second is that although the achievement of the goal is not exclusively dependent on humanity, people nevertheless do bear responsibility for the disclosure of the meaning of the creation. To look on as spectators is not their lot. Ibid., 389-90.

$100 . .$. a number of motives that are presently at work in modern technology, disrupting its meaning, and to assess their tendency. ... It 
Pertama, mengenai technology as applied science. Pemikiran ini membawa kepada peneorian akan teknologi (theorification of technology), di mana perkembangan teknologi ditentukan sepenuhnya oleh science, sehingga kebebasan manusia dibatasi, dan kemungkinan untuk adanya meaning-disclosure tertutup. Akibatnya banyak hal lain yang terjadi, seperti manusia dalam fase produksi hanya menjadi mesin, hilangnya inisiatif, dan tidak adanya penemuan yang menerobos fase design. ${ }^{101}$

Kedua, mengenai teknologi sebagai handmaiden of economic life. Pada saat teknologi direduksi menjadi alat dari ekonomi, maka uang dan keuntungan menjadi kriteria tunggal untuk menilai proses produksi dan teknologi; Penghematan ongkos menjadi fokus; ada dorongan untuk sentralisasi perusahaan menjadi perusahaan besar, dan kreativitas individu tertekan. ${ }^{102}$

should be obvious that these motives will not be found in isolation from each other, and that what is said of one motive may thus be true to some extent of the others as well. Ibid., 409.

101 (View of technology as applied-science) leads to theoretification of technology, that is, to its being reduced to an exercise in theory, in the planning stage. The result is that human creativity as manifest in invention is precluded, and human freedom in technological forming is destroyed. ... As the designer's impulse toward theoretical control gains ground, labor declines in importance of status, meaningful initiatives are thwarted, the achievement of breakthroughs and new discoveries is rendered difficult or impossible, and the disclosure of meaning in technology is impeded. Ibid., 410.

102 Technology is often found in the grip of economic powers. In such instances, the economic value of labor comes to be implemented as the sole norm for the production process, since this criterion is the one that affords the greatest profit. Saving, as the motive of economy, receives exclusive 
Produksi bertambah melampaui kebutuhan karena diarahkan bukan oleh kebutuhan konsumer, tapi dari dorongan komersil. Konsumer terus dijejali dengan produk yang mereka beli karena dorongan iklan tanpa adanya kebutuhan yang nyata. ${ }^{103}$

Ketiga, pemikiran bahwa teknologi adalah neutral instrument. Pikiran ini membuat peranan dan tanggung jawab manusia dalam teknologi terkaburkan. ${ }^{104}$ Meaning dari teknologi menjadi tidak kentara dan manusia mengelak dari tanggung jawabnya akan perkembangan teknologi. Perkembangan teknologi seakan berjalan secara otomatis dan diarahkan dari dalam teknologi itu sendiri, namun sebenarnya sedang menuju kepada arah yang sia-sia (nihilistic tendencies). ${ }^{105}$

emphasis, and the specific meaning of technology as the free giving of form to given materials is totally ignored. Ibid., 410 .

${ }_{103}$ Whenever economism dominates technology and profits assume central significance, the production of goods ceases to be governed by the present needs of consumers. Instead needs are created by way of advertising, for commercial reasons. Ibid., 411.

104 Technology is then regarded as a neutral means of reaching ends appointed by people. Here the real meaning of technology is missed. In fact, the meaning of technology is reduced to its possible significance beyond technology; technology itself not subjected to technological norms. Thus the view that technology is neutral precludes acknowledgment of human responsibility within technology itself. Ibid., 412.

105 This is all the more likely to become the case as people in technology shrug off their responsibility and persist in regarding technological development as neutral and automatic. ... The thesis that technology is a neutral means affords points of contact nicely suited to nihilistic tendencies, for in the absolutization of technology as value-free system of means, every goal and value is placed beyond consideration. Ibid. 
Keempat, pandangan yang melihat teknologi sebagai will to power. Manusia yang menguasai teknologi dengan keinginan akan kuasa (will to power) akan menjadikan teknologi suatu kuasa yang sangat destruktif. Hal ini dipacu lagi dengan kemajuan dan saling terkaitnya teknologi dalam dunia pada zaman ini. ${ }^{106}$ Pengembangan teknologi akan mengalami meaning-disruption karena diarahkan kepada maksud penguasa tersebut dan berfungsi menekan kuasa lain. Demikian pula perkembangan teknologi di pihak yang berlawanan akan berfokus kepada teknologi militer untuk melawan kuasa tersebut.

Kelima, pandangan technology for the sake of technology. Karena pandangan naif, bahwa kemajuan teknologi identik dengan kemajuan umat manusia, maka apapun yang baru pasti lebih baik, dan apapun yang bisa dibuat harus dibuat. Akibat pemikiran ini, perkembangan teknologi lepas dari kontrol manusia; manusia terbebani untuk terus memajukan teknologi dan muncul banyaknya produk teknologi yang tidak betulbetul membawa perkembangan dan akhirnya mencemari kebudayaan dan alam. ${ }^{107}$

106 ... technology as an expression of the lust for power leads in a perverse manner to dictatorship and the tyranny of technology over humanity. ... People inspired by the will to power use technology to support their evil intentions. Technological power then becomes destroying power. Ibid., 413.

107 ... by the expectation or naive belief that technological progress is simultaneously and self-evidently the progress of humanity and society ... whatever can be made ought to be made. ... On the one hand people in technology become burdened as a result, ... on the other hand, they produce 
Sumber dari semua meaning-disruption ini, menurut Schuurman, adalah manusia yang menolak untuk tunduk kepada meaning-dynamis dalam kebebasan (freedom) dan tanggung jawab (responsibility). Manusia mulai melihat teknologi sebagai juru selamat yang membawa mereka mengatasi keterbatasan mereka; tujuan utamanya adalah menjadi Allah atas dunia mereka sendiri. Tapi hasilnya berbeda dari apa yang diharapkannya dan justru memperbudaknya sendiri. ${ }^{108}$ Jadi kepercayaan akan otonomi manusia menjadi perusak dari segala meaning dalam perkembangan teknologi dan menjadikan munculnya meaning-disruption. Akan tetapi karena meaning-dynamis itu tidak dapat dihentikan oleh manusia, maka tetap ada perkembangan yang berjalan dalam teknologi, meskipun banyak mengalami distorsi, korupsi dan limitasi. ${ }^{109}$ Pada akhirnya meskipun perkembangan terjadi, tapi

an abundance of superfluous products or generate serious effects which can put pressure on people outside technology, which has the effect of endangering both culture and nature. Ibid., 413.

${ }_{108}$ Whenever people in technology are ruled by a secularized passion to be almighty and ubiquitous through technology and to be saved from the imperfection of the human condition, the result contradicts their desire. Ibid., 414.

109 Belief in the autonomy of humanity is thus the source of the dislocations of the meaning of technological development; it is the source of the meaninglessness that humankind with technology draws down upon itself as a judgment. ... secularized motives can certainly have "success" in the short run. ... the tensions evoked by autonomous humanity in technology always remain subordinate to the meaning-dynamis... People can bend the direction of meaning-disclosure and they can increase or slow 
mengalami kehancuran di dalam efek penghakiman (judgmental effect)..$^{110}$

\section{TECHNOLOGICAL MEANING DISCLOSURE}

Jadi bagaimana agar meaning-disclosure bisa terjadi dan mengurangi meaning-corruption? Schuurman menunjukkan beberapa hal sebagai konklusi dari analisisnya dalam Technology and the Future. Pada intinya, manusia harus tunduk kepada meaning-dynamis sebagai sesuatu yang normatif. Dalam bidang teknologi, ini berarti melihat meaning khusus dari teknologi dalam koherensi kepenuhan meaning dalam ciptaan. ${ }^{111}$ Di dalam koherensi ini, segala aspek realitas harus diperhitungkan, terutama sekali aspek pistis, karena aspek ini adalah kunci untuk terjadinya meaning-disclosure dan juga yang menunjukkan insufficiency dari perkembangan

down its tempo, but they cannot escape being subject to the meaningdynamis. Ibid., 415.

110 As technological development persists in being controlled by secularized motives, it acquires an increasing catastrophic character. ... as life itself and the things of this technological world are exalted in human thought and convictions are given an independent and absolute status, the meaning-dynamis acquires a judgmental effect. Ibid., 416.

111 The one essential condition for humanity's going on its way in freedom in technological development is that people submit in belief to the meaning-dynamis as normativity for the meaning-disclosure of creation. With respect to technology, this means first of all that people must acknowledge that the specific meaning of technology is contained within the coherence of meaning and directed toward the fullness of meaning and hence toward the Origin of all meaning. Ibid. 
teknologi. ${ }^{112}$ Jadi orang-orang yang terlibat dalam teknologi, terutama engineer dalam fase planning, perlu diarahkan oleh prinsip-prinsip normatif dalam berbagai modes of being. ${ }^{113}$ Bagi Schuurman, absolutisasi suatu aspek bisa dihindari apabila kita melihat dari sisi pengembangan aspek lainnya, sehingga ada semacam transcendental direction ke arah yang lain. Schuurman menjabarkan beberapa bentuk konkret dari prinsip normatif ini sebagai contoh yang dapat dia tawarkan. ${ }^{114}$

Pertama, dari aspek sosial, designing harus melibatkan pemikiran dan kreativitas dari berbagai pihak yang terlibat dalam designing dan forming. Hal ini dapat terlihat apabila kebutuhan dari pihak desainer, produser dan konsumer menyesuaikan perkembangan design dan pekerja yang

${ }^{112}$ A liberating perspective for technological development opens up when it is understood that the specific meaning of technology ought to be led by the normativity of the various post-cultural aspects of our reality, namely, the lingual, social, economic, aesthetic, juridical, ethical, and pistical. Belief is placed last in this sequence not because the disclosure of meaning is rounded off by belief -- on the contrary, belief is precisely the most necessary condition for disclosure -- but because it is in belief that the utter insufficiency of technological development is made clear. Ibid. 416-417.

113 What this means for the engineer is that he must allow himself to be led sequentially by the normative principles of reality's various modes of being; that is, in the human positivizing of technological laws for things and facts, the supra-arbitrary normative principles of the respective modalities must be worked out in relation to what is technological. Ibid., 417.

114 Sepertinya Schuurman melihat bahwa pendetailan prinsip normatif ini harus menjadi bagian dari pekerjaan engineer dan institusi yang terlibat dalam pengembangan teknologi itu. Karena itu list ini tidak perlu kita lihat sebagai sesuatu yang bersifat exhaustive dan lengkap, tapi merupakan sebuah awal dan ide untuk memulai. 
memproduksi tetap mengambil tempat. ${ }^{115}$ Kedua, dari aspek ekonomis, meaning disclosure terjadi dengan pencegahan pembuangan yang tidak efisien, dan usaha untuk mengoptimalkan produksi dan penggunaan benda teknologi. Di sisi lain, keuntungan tetap merupakan perhitungan tanpa bahaya maksimalisasi yang terjadi apabila aspek ekonomis diabsolutkan. ${ }^{116}$ Schuurman juga mendorong pengembangan kembali teknologi lama. ${ }^{117}$ Ketiga, dari aspek keindahan (aesthetic), muncul dalam hubungan harmonis antara semua orang yang terlibat dalam pengembangan teknologi, baik desainer, produser, konsumer, dan otoritas yang menentukan pengembangan ini. Selain itu juga keharmonisan antara alam

115 ... designing ought to involve the exchanging of ideas and the sharing of concerns among all persons and agencies involved in technological designing and forming. Social disclosure of the technological may be observed in the teamwork that goes on during preparation and designing; it is also apparent in the pooling and attuning of the interests of the designers, producers, and consumers. And the important place of the worker in the forming process should not be ignored either. Ibid., 418.

116 We saw that when the economic aspect of technological development is absolutized, a dislocation of meaning occurs: rapid production and mass production must afford the maximum profit; and this is gained at the expense of the individual person and at the cost of overlooking the dangers to the environment posed by waste products. Ibid., 418.

117 Sebagai contoh, perusahaan teknologi yang sukses seperti Apple, tidak selalu menggunakan teknologi yang paling baru, melainkan menggunakan teknologi yang lebih kuno dengan design yang lebih baik. Teknologi touch screen yang dipakai iPad misalnya, sudah lama ditemukan, namun Apple berhasil mendesain ulang dan mengubah cara dunia dalam menggunakan komputer. 
dan teknologi. Keempat, dari aspek keadilan (juridical) bisa dikerjakan dengan adanya promosi yang adil dalam pengembangan teknologi yang beragam. Selain itu masyarakat dilindungi dari kuasa superior yang memonopoli teknologi dan menekan kebebasan. Juga aspek keadilan dikembangkan apabila ada sebuah compromise antara seluruh individu yang terlibat dalam teknologi. ${ }^{118}$ Aspek keadilan juga tampak dari historical judgment dari Tuhan karena absolutisasi yang dikerjakan oleh manusia. ${ }^{119}$ Kelima, dalam aspek etika atau moral, yang terjadi apabila para teknologis bekerja karena dorongan kasih, baik kasih kepada produk, kepada pengguna, dan terlebih lagi kepada sesama manusia secara umum, dan kepada alam ciptaan Tuhan. ${ }^{120}$ Terakhir, meaning-disclosure dalam aspek iman (pistis), di mana manusia melihat pekerjaan teknologisnya sebagai misi di hadapan Allah dalam tanggung

118 First, legal institutions must see to it that technology is promoted. Secondly, they have the task of protecting people from the superior force of any misdirected technological development. ... justice is reflected in the reaching of compromises in technology. ... the purchaser, the contractor, the financier, the plant management, the designing department, the people who work with their hands -- all these are participants in a compromise ./ and all have to make concessions of greater or lesser importance. Ibid., 419.

119 A stiffened or absolutized technological development cannot fail to bring judgment down upon itself, ... "historical judgment" will appear. Ibid., 420.

${ }^{120}$ Love will express itself in a good choice and a proper use of available materials and objects and in a good, artisanlike finishing of technological products. But the care and responsibility of the technician ought to be directed above all toward the neighbor, ... and toward nature ... . Ibid., 420. 
jawab. Jadi aspek ini menjadi kunci dalam disclosure. Manusia menyadari bahwa segala sesuatu harus diarahkan kembali kepada Tuhan sebagai sumber segala meaning. Teori dan filsafat manusia tidaklah cukup di dalam dirinya sendiri, melainkan melayani kepercayaan. Tempat mereka adalah dalam mengomunikasikan ide kepada orang lain yang bekerja dalam teknologi. ${ }^{121}$

\section{PENYEBAB DAN SOLUSI OTONOMI TEKNOLOGI}

Di bagian akhir dari Technology and the Future, Schuurman menyelidiki bagaimana teknologi menjadi sebuah otonomi sehingga kita dapat berusaha untuk menghindarinya. Schuurman melihat bahwa keunikan struktur teknologi modern menyebabkan ide otonomi ini muncul. ${ }^{122}$ Pertama, karena adanya pemisahan antara fase perencanaan (design) dan eksekusi (execution). Seorang teknologis sebagai individu tidak lagi terlibat dalam keseluruhan pengembangan teknologi. Dia tidak memiliki overview akan seluruh proses dan tujuan dari sebuah produk teknologi. Kedua, karena kompleksitas dalam design, maka dibutuhkan kerja sama antara banyak orang dan

${ }^{121}$ Belief is always the boundary-function and horizon of meaningdisclosure. ... philosophical-scientific thought is not self-sufficient ... Theoretical thought can serve only to point to this transcending in faith; it can only approach its substance by describing and idea, as it were - and idea that ought to lead people in their work in technology. Ibid., 421.

${ }^{122}$ At the outset it is necessary to have within our purview the unique structure of modern technology, for that structure, in a remarkable way, gives rise to the notion that technology is autonomous. Ibid., 421. 
juga penggunaan komputer dalam menyelesaikan kompleksitas perhitungan. Sehingga seorang desainer sebagai individu terdorong ke latar belakang dan tidak lagi merasa menjadi bagian signifikan dalam pengembangan teknologi. ${ }^{123}$

Ketiga, karena begitu cepatnya penemuan teknologi baru. Untuk dapat memberikan norma yang tepat bagi sebuah teknologi baru, dibutuhkan refleksi dari komunitas (preliminary communal reflection) yang menggunakan dan mengalami dampaknya. Namun dengan cepatnya introduksi akan teknologi baru, manusia selalu tidak siap dan akhirnya memberikan refleksinya dengan menggunakan standar yang lama. ${ }^{124}$ Keempat, karena struktur dari produk teknologi modern (modern panoply of tools and instruments). Mesin dan instrumen teknologi modern, seperti komputer, berjalan sendiri dan tidak terus-terusan bergantung kepada pembuatnya. Pembuatan komputer dan pembuatan kode untuk menjalankan komputer dikerjakan oleh orang berbeda, sehingga dapat muncul hal-hal yang tidak diperkirakan sebelumnya oleh manusia (surprise). Perlahan manusia mulai berserah kepada

${ }^{123}$ Design activities have become so multifariously demanding and complex that the individual designer is relegated to the background. ...... people can easily be deprived of the possibility of gaining a clear overall picture of their own areas of responsibility, and they can thereby come to feel at last like insignificant links in technological development. Ibid. 422.

${ }^{124}$ Norms can only be positivized ... after preliminary communal reflection has taken place, and it is precisely this prerequisite that appears to be canceled and precluded by the dynamics of technological development. ... people measure its latest advances against the yardstick of outdated norms that cannot suffice in new situations. Ibid., 422. 
keputusan komputer. ${ }^{125}$ Kelima, karena sentralisasi teknologi. Banyak teknologi dikembangkan, pada awalnya, karena dorongan militer dan industrial dengan pemerintah sebagai pengatur umum. Akibatnya kekuatan teknologi berkaitan erat dengan kekuatan pemerintahan, sehingga pengembangan teknologi terdorong kepada satu arah dan terjadi sentralisasi. Dengan demikian terasa adanya kekuasaan otonom dari teknologi. ${ }^{126}$

Pada puncaknya, otonomi terjadi karena keinginan manusia untuk menyelamatkan diri dengan kekuatannya sendiri. Bagi Schuurman, permasalahan teknologi adalah permasalahan arah hati (religious direction), di mana manusia sekuler yang telah menolak Allah kemudian berusaha untuk mendatangkan keselamatan dengan caranya sendiri. Keberhasilan teknologi modern dalam menjawab permasalahan membuat manusia sangat optimis dan mengikuti teknologi secara religious. Akhirnya tanpa sadar mereka telah diatur oleh teknologi, dan berlaku seakan mereka adalah bagian dari

125 ... the functioning machine runs quite independently of its makers. ... the results, within certain limits, do have the character of a surprise. ... the user has not a glimmer of the criteria by which the contraption may be functioning. He must yield to it, trustingly. Ibid., 423.

126 ... technology is being developed under the influence of the huge industrial-military complex, with the state appearing increasingly in the role of the great regulator. Technological power is linked in the popular mind to organizational and bureaucratic power, which comes to be regarded as the anonymous power of technology. Ibid., 423. 
teknologi. ${ }^{127}$ Perspektif yang membebaskan (liberating perspective) baru dapat diperoleh pada saat manusia mengarahkan dirinya kembali kepada Tuhan. ${ }^{128}$ Tentunya hal ini hanya dapat diperoleh dalam partisipasi manusia yang melalui iman datang kepada Kristus yang telah menebus ciptaan. ${ }^{129}$

${ }^{127}$ In its pretended autonomy, humanity thought it could save itself, and it still intends to do so. Modern technology, through its success and progress, has proved especially inspiring to people. ... humanity has come to follow in technology's train in a religious sense ... People permit themselves to be ruled by technology. They forfeit the ability to see through the appearance of a technological and organizational automatism. And that carries with it the consequence that human beings go out and act as if they were technological things of some sort. Ibid., 424.

${ }^{128}$ In short, it is necessary to the termination of the idea of the autonomy of technology that humanity give up the idea of its own autonomy and, consequently, its high-handed pursuit of freedom and salvation. Humanity must instead submit, in freedom and responsibility, to the meaning-dynamis of the creation. "Until this calamitous quest for 'do-ityourself' salvation is recognized as something which stands in the place of true belief, everything will remain as it has been." Should this fundamental condition be fulfilled, however, there will be perspective again. Ibid., 426-27.

129 The fall into sin broke humanity's power, and nature was cursed. ... Humanity is no longer in fit condition to administer and disclose nature. On the contrary, people are constantly threatened by nature and must defend themselves against it. ... Restoration is given in Jesus Christ. He heals the brokenness of the entire creation and turns it again, in its fullness, toward God, the Origin. Jesus Christ came into a world broken by sin to undergo chastisement of death for sin. He also fulfills humanity's task of having custody over creation and opening it up. Jesus Christ saves and fulfills creation. Ibid., 432. 


\section{KESIMPULAN}

Menurut Schuurman, sumber permasalahan teknologi adalah technicism, yakni pengharapan dalam teknologi, dan otonomi teknologi yang sebenarnya muncul karena otonomi manusia yang menolak Tuhan dan kemudian bergantung kepada teknologi. Akibat penolakan tersebut, manusia membentuk kebudayaan Babel dan potensi teknologi dalam ciptaan, yang adalah sebuah meaning-dynamis tidak mengalami meaning-disclosure yang sehat, melainkan menimbulkan meaning-disruption.

Meskipun Schuurman melihat bahaya perkembangan teknologi, Schuurman tetap melihat kemungkinan adanya liberating perspective karena otonomi teknologi bukan ada pada teknologi itu sendiri, tapi pada usaha otonomi manusia. Untuk itu, manusia harus menundukkan diri di bawah meaning dynamis dan menjalankan prinsip-prinsip normatif yang mengarahkan perkembangan teknologi dalam kepenuhan segala aspek kehidupan.

Indonesia, sebagai salah satu negara berkembang, sering terdorong untuk mengadopsi hasil teknologi yang telah dikerjakan oleh negara-negara berkembang lainnya. Akan tetapi bersamaan dengan perkembangan tersebut, ada bahaya yang terdapat dalam teknologi tersebut. Bahaya ada apabila kita menerima segala macam teknologi dan akhirnya juga mewarisi keburukan yang telah dialami oleh negara berkembang. Di sisi lain, kita tidak mungkin menolak perkembangan teknologi sama sekali. Di tengah kedua sikap terhadap teknologi, baik yang positif maupun yang negatif, 
usulan Schuurman bisa menjadi jalan tengah yang baik. Di satu sisi, pandangannya memiliki kewaspadaan terhadap pengaruh kejatuhan di dalam perkembangan teknologi yang perlu diawasi. Di sisi lain, pandangan ini masih menaruh pengharapan dalam pengembangan teknologi. Terlebih lagi, pandangan ini juga memberikan solusi praktis yang dapat dipertimbangkan oleh pembuat kebijakan dalam pengembangan teknologi dan juga bagi para teknologis. 